\title{
TRADE BETWEEN CENTRAL AND EASTERN EUROPEAN COUNTRIES AND THE RUSSIAN FEDERATION IN THE CONTEXT OF SANCTIONS AND COUNTER-SANCTIONS
}

\section{Livia CEBOTARI}

Economics and International Affairs Doctoral School, Bucharest University of Economic Studies, Bucharest, Romania

cebotari.livia.2014@gmail.com

\begin{abstract}
The year 2014 marked the deepest crisis in EU-Russia relations since the dissolution of the Soviet Union. The bilateral relations cooled down because of the Ukrainian conflict. The EU started to impose restrictive measures on Russian Federation and Russia has responded by imposing counter-sanctions. The sanctions imposed by European Union in conjunction with the counter-sanctions adopted by the Russian Federation on EU food imports had massive consequences on the bilateral trade. The main purpose of this research is to identify and evaluate the impact of sanctions and counter-sanctions on trade in goods between eleven Central and Eastern European Countries and the Russian Federation. This paper tries to determine the factors that can explain why, after the adoption of economic sanctions, some Central and Eastern European Countries recorded losses higher than others. The research methodology combines tools of both quantitative analysis and qualitative analysis.
\end{abstract}

Keywords: European Union, Russian Federation, economic relations, economic sanctions

JEL classification: F10, F50, F51

\section{Introduction}

The year 2014 marked the deepest crisis of the relations between the EU and Russia since the dissolution of the Soviet Union. The bilateral relations cooled down as the conflict in Ukraine evolved. The factor triggering the political crisis was the suspension by the Ukrainian government of the preparation process for signing the Association Agreement between Ukraine and the European Union in November 2013. It followed the Vilnius Eastern Partnership Summit, where the Ukrainian president at that time, Viktor Yanukovych, refused to sign the partnership agreement with Brussels. The decision of the Ukrainian government and the refusal of the president generated protests in the centre of Kyiv. Though at first considered as insignificant, the demonstrations turned into mass manifestations and extended in several towns of Ukraine. The situation further escalated and the following events: the removal of the Ukrainian government from power, the referendum in Crimea and the annexation of the peninsula to the Russian Federation, the military conflict in the Donbas region have increased even more the tension between the Russian Federation and Occident. 
In March 2014, the European Union condemned the actions of Russia in Ukraine and imposed the first wave of sanctions against the Russian Federation. The EU imposed diplomatic measures, individual restrictive measures (asset freeze and travel restrictions), restrictions on economic relations with Crimea and Sevastopol, economic sanctions and restrictions on economic cooperation. The economic sanctions imposed by the European Union targeted the exchanges between the EU and Russia in various sectors. These restrictive measures limited the access for certain Russian banks and companies to EU primary and secondary capital markets and did not allow any forms of financial support and intermediation in favour of the Russian financial institutions. Restrictive measures also prohibited the import, export and direct or indirect transfer of all defense-related materials, as well as dual-use items that could be used for military purposes or used by Russian military end-users. The sanctions curtailed the access of Russia to certain sensitive technologies and services that can be used in the Russian energetic sector, for instance, in oil production and exploration. (European Council, EU restrictive measures in response to the crisis in Ukraine). In response, the Russian Federation introduced an embargo on agricultural and food exports from the European Union. There was a ban on the imports of fruits and vegetables, meat and meat products, certain kinds of fish, milk and dairy products from the EU. All restrictive measures, both those applied by the EU and the counter-sanctions adopted by Russia, are constantly reviewed and are subject to periodical renewals.

\section{Literature review}

Studying the specialised literature that approaches the topic of restrictive measures imposed by the European Union against the Russian Federation, it has been determined that, up to the present, two research direction have been identified. Some authors (Gurvich, E., Prilepskiy, I., (2015); Ilina E. (2015); Russell M. (2018), analysed the efficacy of the sanctions imposed by the EU, referring only to the impact they had on the economy of Russia. Others (Dolidze T. (2015); Bond I., Odendahl C., Rankin J. (2015); Giumelli (2017); Oxenstierna (2018)) preferred to build a clearer picture, examining the costs borne by the EU following the adoption of sanctions.

The report prepared at the request of the European Parliament's Committee on International Trade (DG EPPD (2017)) presented the effects of the restrictive measures on Russia's economy, as well as the way in which sanctions have affected the EU Member States. Dolidze (2015) declared that the restrictive measures had a boomerang effect, thus the sanctions adopted by the EU combined with Russia's embargo on food imported from European Union created a situation of loss for all economic participants involved. Giumelli (2017) studied the effects of the sanctions applied referring to each country separately, not on the level of the entire European Union. The researcher stated that after the adoption of restrictive measures, all EU countries saw a reduction in their exports to the Russian Federation, but not all EU Member States felt the negative effects equally. Oxenstierna (2018) pointed out that the European Union is a multilateral sender, acting uniformly when it comes to imposing restrictive measures, but the consequences of these sanctions and counter-sanctions vary considerably from 
one Member State to another. Bali (2018) brought attention to the distributive impact of restrictive measures, emphasizing that some EU countries were more affected than others. Havlik (2019) found that the economic effects on EU Member States differ according to their level of exposure to the Russian market.

\section{Research objectives and methodology}

The aim of this paper is to evaluate the impact of sanctions and counter-sanctions on bilateral trade between EU Member States from the Central and Eastern European region and the Russian Federation in the period 2014-2019. The practical purpose of the investigation consists in determining the factors that can explain why the restrictive measures had an uneven impact on the countries in this region and on their interaction with Russian Federation.

The term Central and Eastern European Countries (CEECs) has several definitions. That's why it is important to clarify that in the context of this paper, the term Central and Eastern European Countries refers to the definition given by the Organization for Economic Cooperation and Development, except Albania which is not an EU member state. Therefore, in this research, the term Central and Eastern European Countries refers to the group of countries including Bulgaria, Croatia, the Czech Republic, Hungary, Poland, Romania, the Slovak Republic, Slovenia and the three Baltic states: Estonia, Latvia and Lithuania.

The research methodology combines the specific tools of quantitative analysis with that of qualitative analysis. The information collected from official documents of the European Parliament and the European Commission, academic articles and studies conducted by several think-tanks (European Parliamentary Research Service (EPRS), Centre for European Policy Studies (CEPS), Centre for European Reform (CER), The Vienna Institute for International Economic Studies (wiiw), etc.) were analysed. Also, the research relies on database disseminated by Eurostat. Statistical data on trade in goods between Central and Eastern European Countries and Russia for the period 2010-2019 (quantity, value of imports and exports) were collected and processed. The structure of imports and exports of goods was also analysed by using the Standard International Trade Classification (SITC). The main sectors of this classification system are: food and live animals; beverages and tobacco; crude materials, inedible (except fuels); mineral fuels, lubricants and related materials; animal and vegetable oils, fats, waxes; chemicals and related products; manufactured goods classified chiefly by material; machinery and transport equipment; miscellaneous manufactured articles; commodities and transactions not classified elsewhere (Eurostat).

\section{Trade between Central and Eastern European Countries and Russia}

Analyzing the historical data, it can be stated that the economic sanctions have negatively influenced the trade between the EU and Russia, but have not changed its structure. The EU's exports to the Russian Federation were and remain dominated by finished products (machinery and transport equipment, chemicals and medicines, and other manufactured products), while the imports are led by raw materials (oil, natural gas, fuels and coal). The same structure is also present in the 
trade of products between the Russian Federation and the EU Member States from Central and Eastern European region.

In 2013, the structure of EU Member States from Central and Eastern Europe exports to the Russian Federation showed that four product groups concentrated $84,94 \%$ of deliveries, respectively: machinery and transport equipment $(46,41 \%)$, chemicals and related products $(14,79 \%)$, manufactured goods classified chiefly by material (12,40\%) and miscellaneous manufactured articles $(11,34 \%)$. In the same year, the structure of EU Member States from Central and Eastern Europe imports from Russia showed that four product groups represented $95,29 \%$ of total purchases: mineral fuels, lubricants and related materials $(83,30 \%)$, commodities and transactions not classified elsewhere $(5,52 \%)$, chemicals and related products $(3,35 \%)$ and manufactured goods classified chiefly by material $(3,12 \%)$.

In 2019, the same four product groups concentrated $88,92 \%$ of exports from the CEECs' to Russia (machinery and transport equipment $(45,17 \%)$, chemicals and related products $(19,13 \%)$, manufactured goods classified chiefly by material $(12,67 \%)$ and miscellaneous manufactured articles $(11,95 \%)$ ) and $91,99 \%$ of CEECs total imports from Russia (mineral fuels, lubricants and related materials $(72,85 \%)$, manufactured goods classified chiefly by material $(8,10 \%)$, chemicals and related products $(5,84 \%)$ and commodities and transactions not classified elsewhere (5.20\%)).

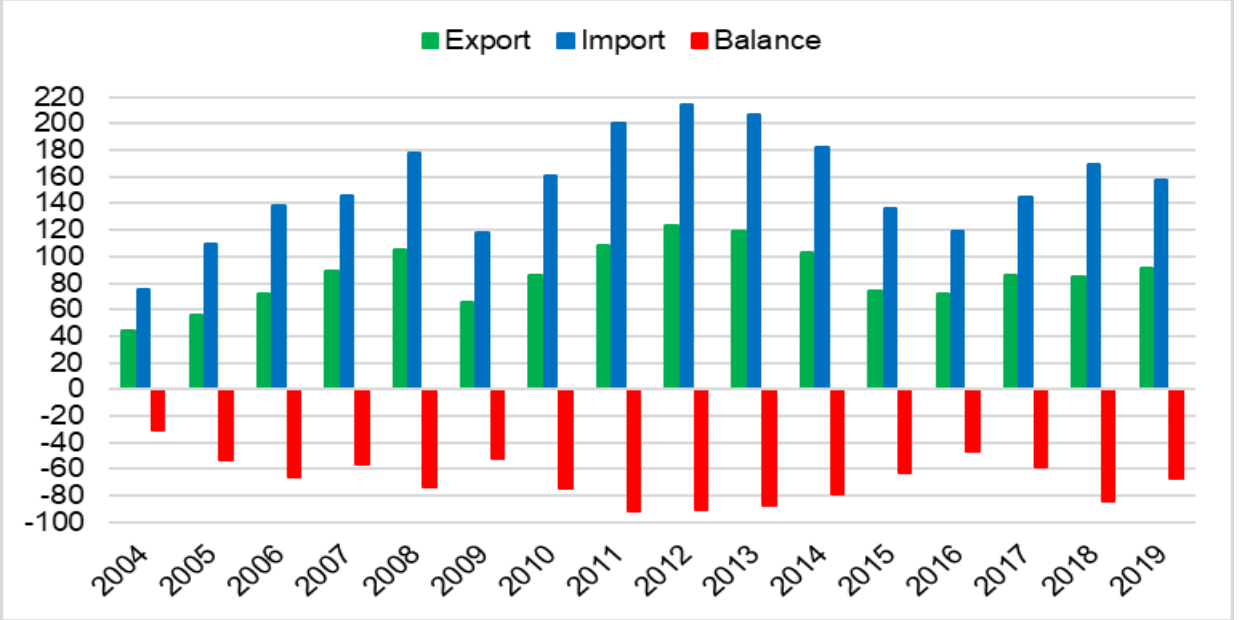

Figure 1: EU-Russia trade in goods, billion $€$ Source: Author's projection using Eurostat database (2021)

The statistical data showed a decrease in the volume of trade between the EU and the Russian Federation in the 2014-2018 period, compared to the 2010-2014 period (see Figure 1). The same trend can be noticed in regard to trade between CEECs and Russia (see Figure 2). Between 2014-2016, besides the restrictive measures adopted by the EU against Russian Federation and the countersanctions adopted by Russia, the evolution of bilateral trade flows was also influenced by the reduction of oil prices, which, in turn, caused the depreciation of the Russian rouble. Though such circumstances cannot be ignored, the aim of the paper is not to separate the effects of sanctions and counter-sanctions from the consequences of other factors, but to analyse the evolution of imports and exports 
of goods during the period 2014-2019, the time interval during which the restrictive measures were applied.

Poland, followed by Lithuania and Czech Republic are the states with the highest exports to Russia. On the other side, the top importers are Poland, Lithuania and Hungary.

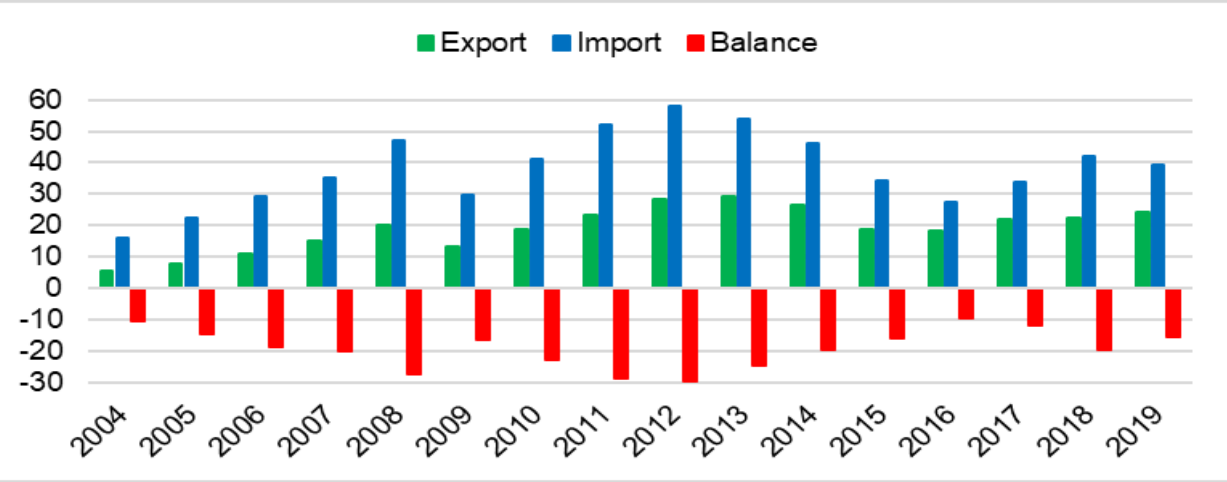

Figure 2: Trade between CEECs and Russia, billion $€$ Source: Author's projection using Eurostat database (2021)

\section{Impact on bilateral trade}

\section{Poland}

In 2013 Poland had $6,80 \%$ of EU exports to Russia and $27,91 \%$ of the CEECs' exports. In 2016, these shares had increased to $7,19 \%$ and $28,55 \%$, but Poland's export to Russia had decreased by EUR 2,91 billion in 2016, compared to 2013. Since 2017 the Polish export to the Russian Federation has begun to gradually recover, reaching EUR 7,43 billion (EUR 0,68 billion less than in 2013) (see Figure 3).

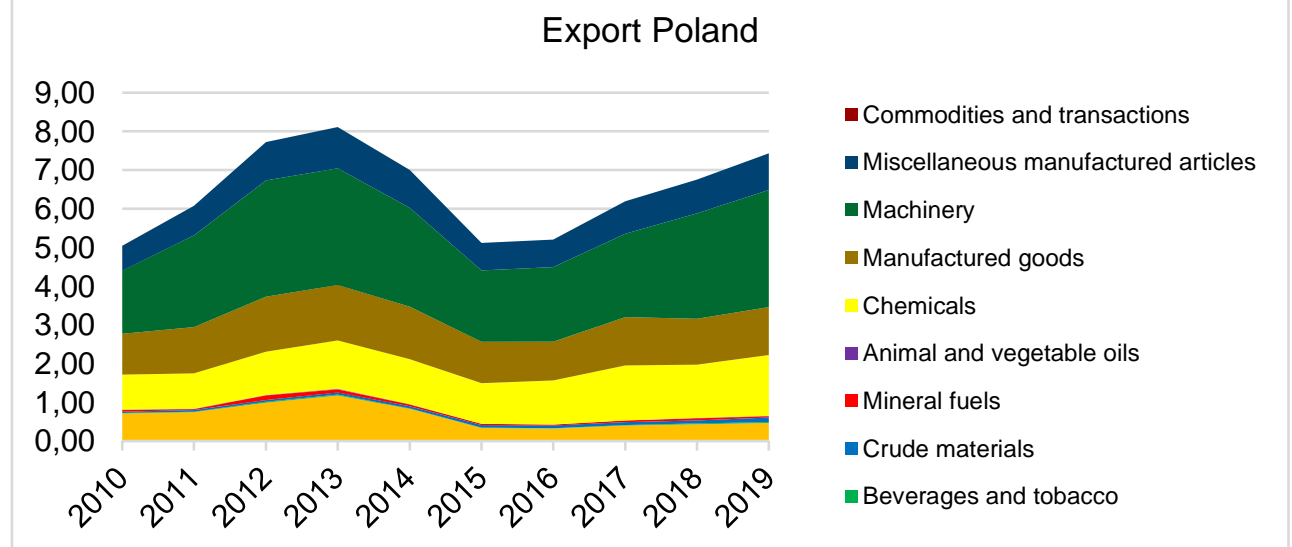

Figure 3: Poland's export to Russia, billion $€$

Source: Author's projection using Eurostat database (2021)

In 2013 Russian exports to Poland corresponded to 9,04\% of total EU imports from the Russian Federation and $34,68 \%$ of the CEECs' total imports from Russia. In the period 2014-2019, the shares were pretty much the same, but in nominal 
terms, Polish imports from the Russian Federation decreased (see Figure 4). In 2016, Russia imported from Poland goods amounted to EUR 10,28 billion, while in 2019, they amounted to EUR 14,23 billion (with EUR 5,76 billion, respectively EUR 4,43 billion less than in 2013, respectively). It is worth mentioning that Poland is the largest food exporter to Russia from Central and Eastern European Countries.

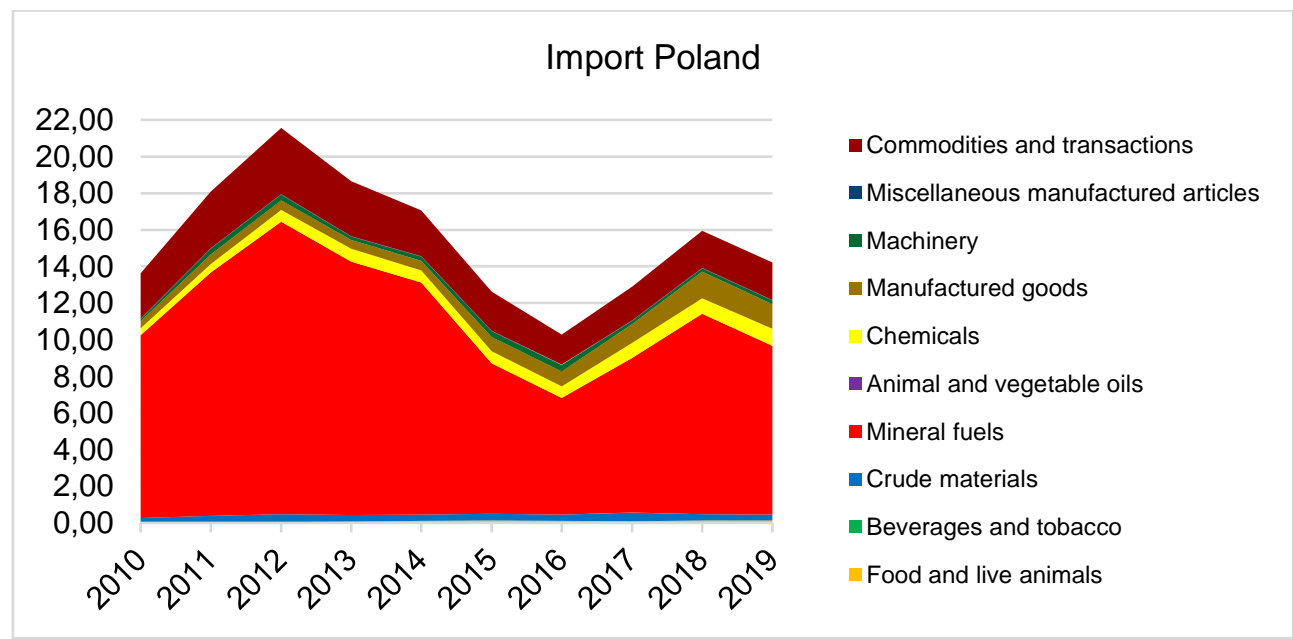

Figure 4: Poland's import from Russia, billion $€$

Source: Author's projection using Eurostat database (2021)

In the period 2013-2019, the export of foods declined by $60 \%$, reaching the lowest value in 2015. Also, exports of animal and vegetable oils decreased by $60,8 \%$ in 2019 compared to 2013. Machinery exports recorded the lowest value in 2015 (EUR 1,84 billion), but gradually recovered, and in 2019 they reached the level of 2013 (EUR 3 billion). Exports of chemicals did not decrease significantly in 20142016. Starting with 2017 they have increased and even exceeded the 2013 value.

\section{Lithuania}

In 2013 Lithuanian export to the Russian Federation corresponded to $4,08 \%$ of total EU export to Russia and $16,75 \%$ of the CEECs' total export to Russia. In 2019 , the respective figures were slightly higher, $4,56 \%$ and $17,24 \%$. Lithuania and Romania were the only states from Central and Eastern European Countries that had an increase in the volume of exports in 2014 compared to 2013. In the case of Lithuania, the increase in that year can be explained by a rise in exports of machinery. Machinery is Lithuania's biggest export product. Export of machinery declined in 2015, but it recovered in 2017. However, in the next two years (2015 and 2016), total exports from Lithuania to Russia experienced a deep decline. Like other CEECs Lithuania has suffered from a sharp decline in its food export that fell by $85 \%$ in 2014-2019. Lithuania has experienced increases of export of crude materials, chemicals and in the last two years (2018 and 2019) of beverages (see Figure 5). 


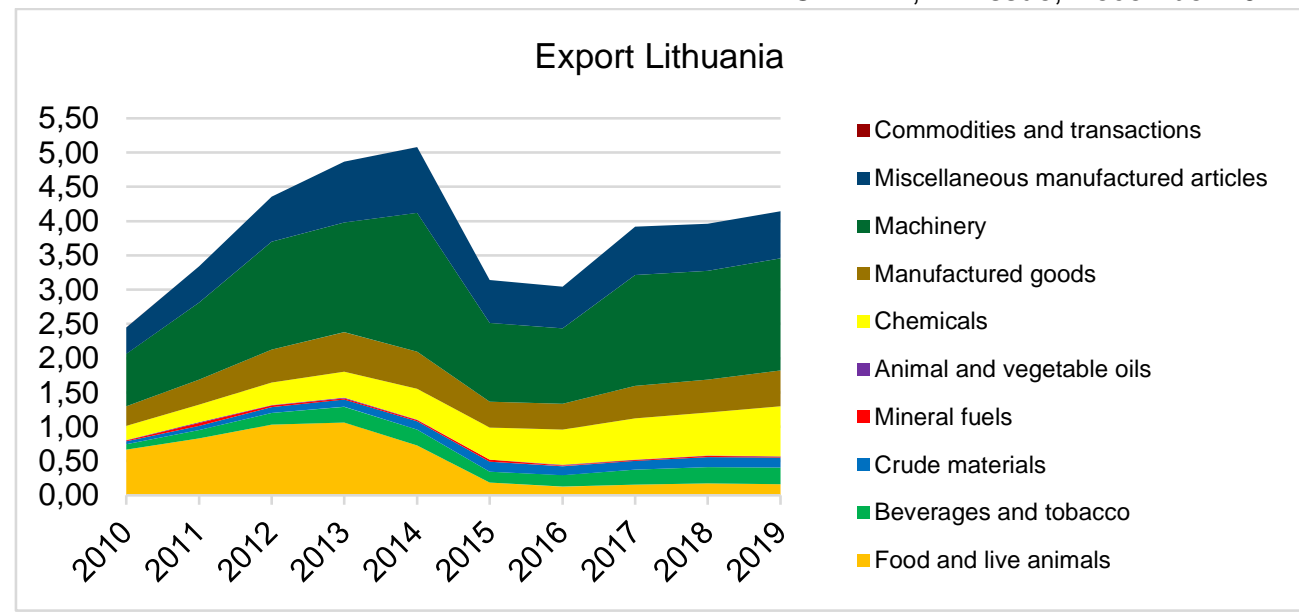

Figure 5: Lithuania's export to Russia, billion $€$ Source: Author's projection using Eurostat database (2021)

In the period 2014-2019, the total exports from Lithuania to the Russian Federation and the imports from Russia both decreased. Mineral fuels, lubricants and related materials are the most important goods that Lithuania imports from Russia and their value decreased dramatically during the analyzed period. Beverages and tobacco imports remained relatively constant. Imports of food, crude materials and manufactured goods have increased significantly since 2015 (see Figure 6).

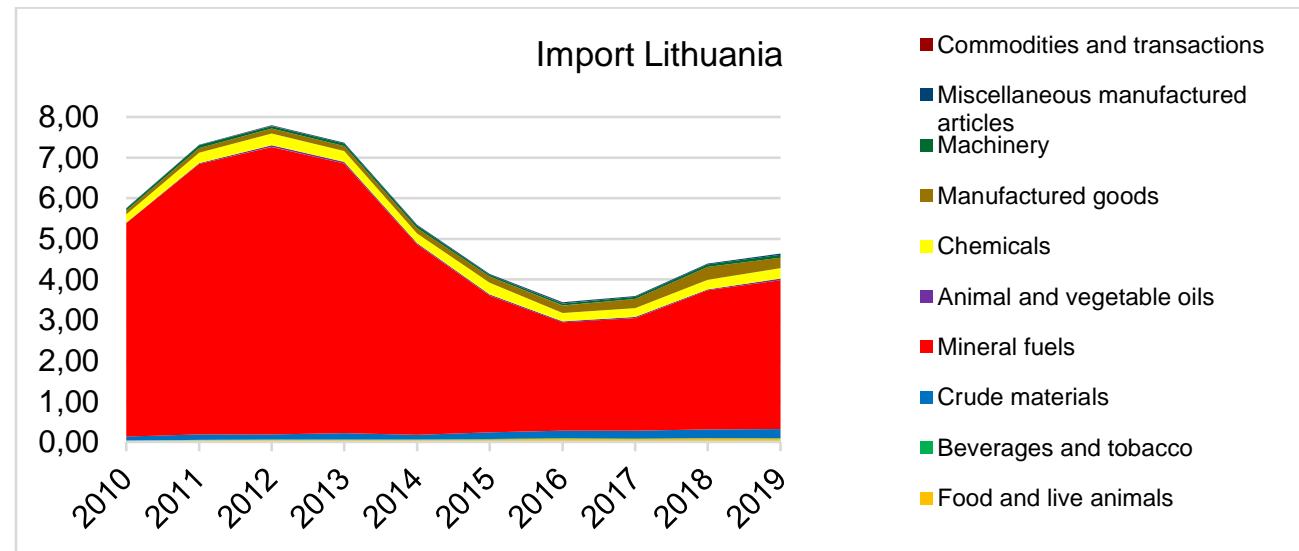

Figure 6: Lithuania's import from Russia, billion $€$ Source: Author's projection using Eurostat database (2021)

\section{Czech Republic}

The Czech Republic's share of export in the EU's total export to Russia was relatively constant between 2013 and 2019, varying between 3,75\% and 4,18\%. The same trend can be noticed in regard to its share of the CEECs' export to Russia (around 15\%). Even so, in the period mentioned above, Czech Republic's total export to Russia has declined. Its largest export was in machinery, which 
declined by $20 \%$. Export of food, beverages and miscellaneous manufactured articles kept their value relatively constant and registered increases in the last years of the analyzed period (see Figure 7). Also, total Czech imports from Russia have gradually fallen from EUR 5,38 billion in 2013 to EUR 2,94 billion in 2019. In 2013 the Czech Republic had 2,60\% of EU imports from Russia and 10,00\% of the CEECs' imports. After six years, the country had $1,86 \%$ of EU imports from Russia and 7,43\% respectively. In 2014-2019, imports of beverages and machinery from Russia to the Czech Republic have increased, while imports of crude materials and mineral fuels have recorded declines (see Figure 8).

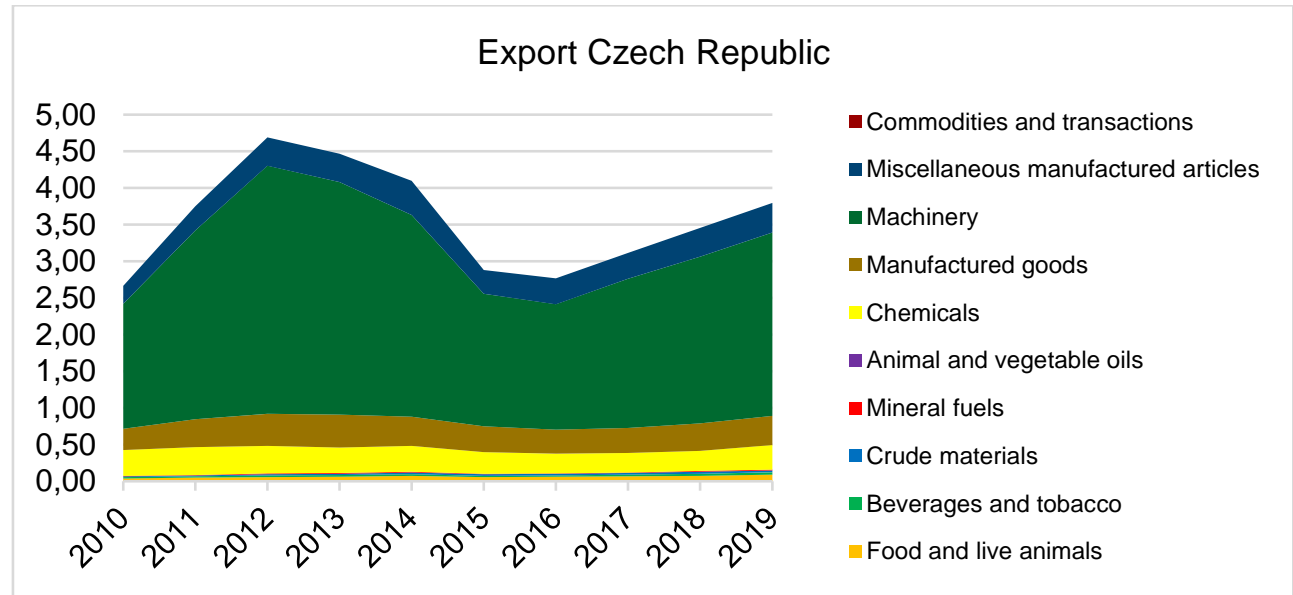

Figure 7: Czech Republic's export to Russia, billion $€$ Source: Author's projection using Eurostat database (2021)

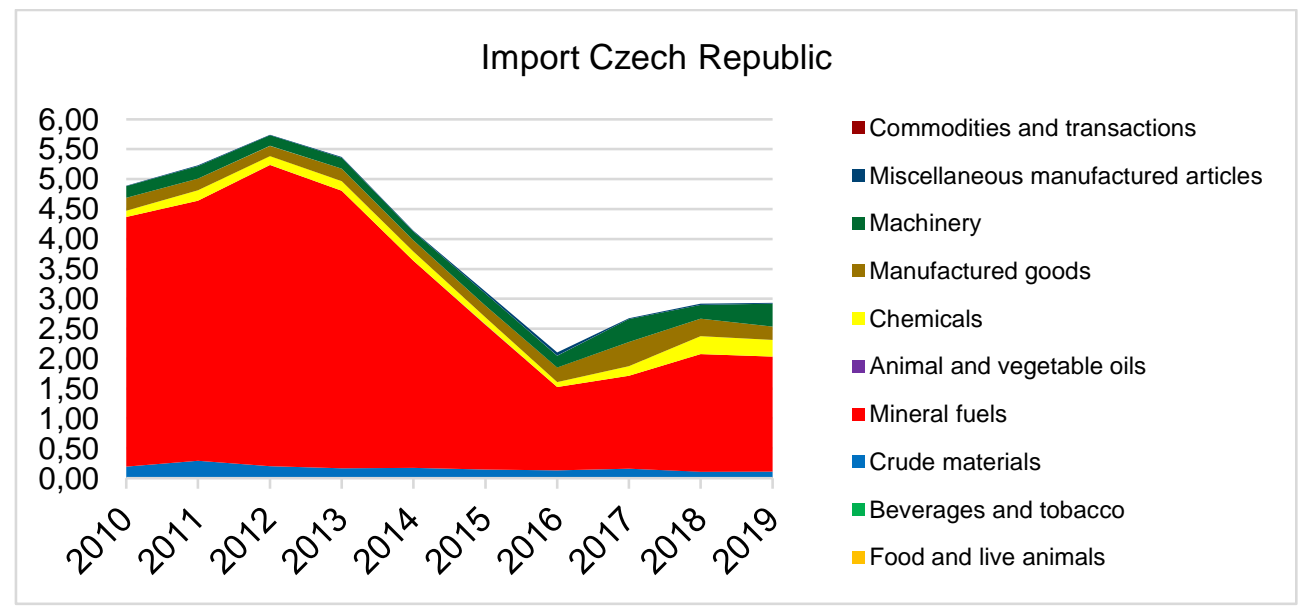

Figure 8: Czech Republic's import from Russia, billion $€$

Source: Author's projection using Eurostat database (2021)

\section{Latvia}

Latvia suffered a significant decline in 2015 and 2016, but it managed to recover its former export level and even outperformed it in 2018. Latvia had 1,47\% per cent of 
EU total export to Russia in 2013 and 6,05\% of the CEECs' export. In 2019 these shares had risen slightly to $2,18 \%$ and $8,24 \%$. Most important Latvia's export goods to Russia are beverages and machinery. Export of these categories of goods registered a decrease in the years 2014-2016, after which in the period 2017-2019 the imported values increased. Food export declined significantly and it has not recovered. Export of chemicals rose by EUR 0,05 billion and of miscellaneous goods by EUR 0,11 billion (year 2019 compared to 2013). Export of mineral fuels and animal and vegetable oils have also declined (see Figure 9).

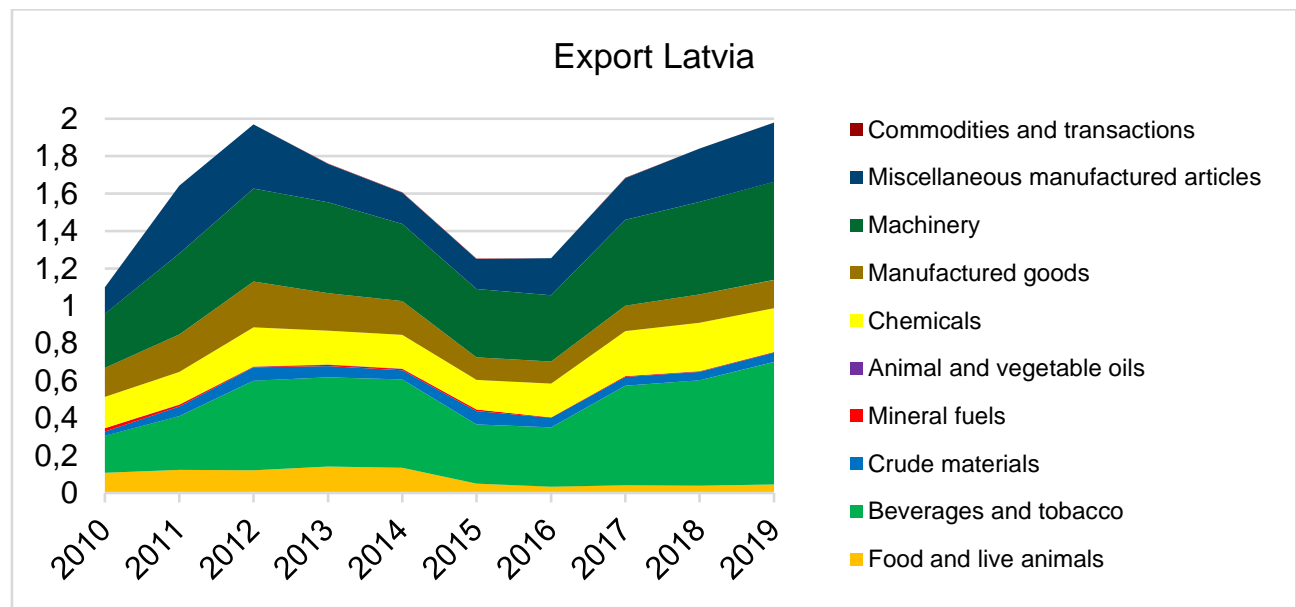

Figure 9: Latvia's export to Russia, billion $€$ Source: Author's projection using Eurostat database (2021)

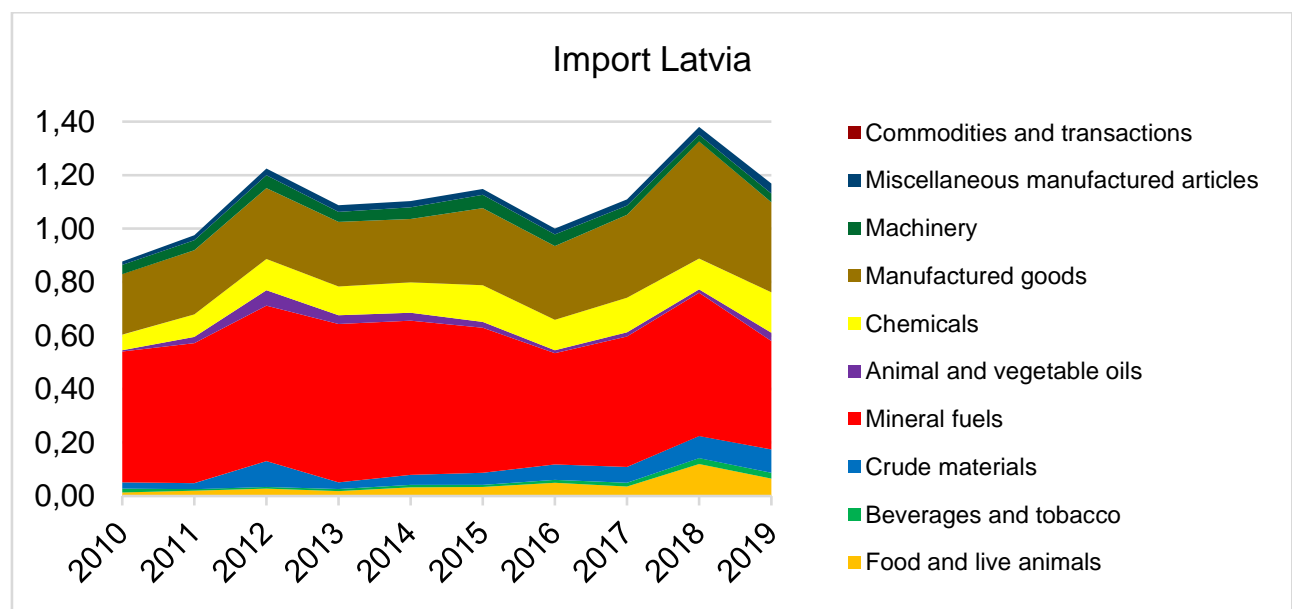

Figure 10: Latvia's import from Russia, billion $€$ Source: Author's projection using Eurostat database (2021)

Latvia's imports from Russia between 2013 and 2019 have been constant (around EUR one billion). Its share in total EU imports to Russia increased from $0,53 \%$ in 2013 to $0,74 \%$ in 2019 and that of the CEECs' imports from 2,02\% to 2,96\%. The 
main goods imported from Russia by Latvia are, as in the case of the other Central and Eastern European Countries, mineral fuels. In the period 2014-2019, the import of this type of goods decreased. At the same time, imports of food, beverages and tobacco and crude materials increased considerably. Imports of chemicals and manufactured goods also increased (see Figure 10).

\section{Romania}

In 2013 Romania had $1,16 \%$ of total EU export to Russia and $4,76 \%$ of the CEECs' total export. Romania's export to Russia consists primarily of machinery, chemicals and manufactured goods. In 2014, two of these three categories, namely machinery and chemicals registered an increase, after which in 2015 there was a sharp decline. Overall, these three types of export goods have declined between 2013 and 2019. Food exports increased in 2014 compared to 2013, after which they gradually decreased, and in 2019 they reached the lowest value during the period 2013-2019. However, there are several types of goods that have increased during the same period, for example: beverages and crude materials. Export of these goods is smaller by value but the increase compensates to some degree for the losses in the primary export goods (see Figure 11).

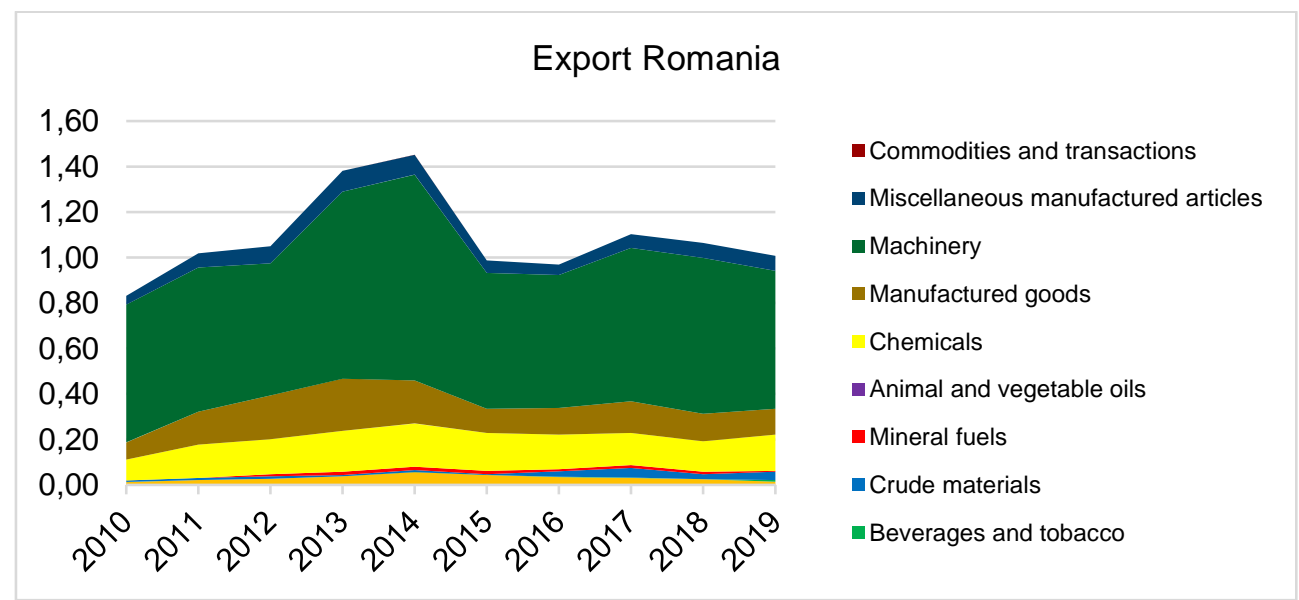

Figure 11: Romania's export to Russia, billion $€$

Source: Author's projection using Eurostat database (2021)

During these 6 years, the total value of imports from Russia to Romania has fluctuated (EUR 2,36 billion in 2013 and EUR 3,09 billion in 2019). From 2013 to 2016, total imports declined, after which they began to increase. In 2013 Romanian imports from the Russian Federation corresponded to 1,14\% of total EU imports from the Russian Federation and 4,39\% of the CEECs' total imports from Russia. In 2019, the respective figures were slightly higher, $1,96 \%$ and $7,84 \%$, respectively. Food imports decreased in 2014 and 2015, after which they recovered and even exceeded the values recorded in 2013. Beverage imports increased significantly from EUR 0,24 billion in 2013 to EUR 4,53 billion in 2019. Imports of chemicals decreased in the period 2014-2016, after which they recovered starting with 2017, and in 2019 the value registered in 2013 almost doubled. Also, during the analyzed period, the imports of manufactured goods and machinery increased considerably (see Figure 12). 


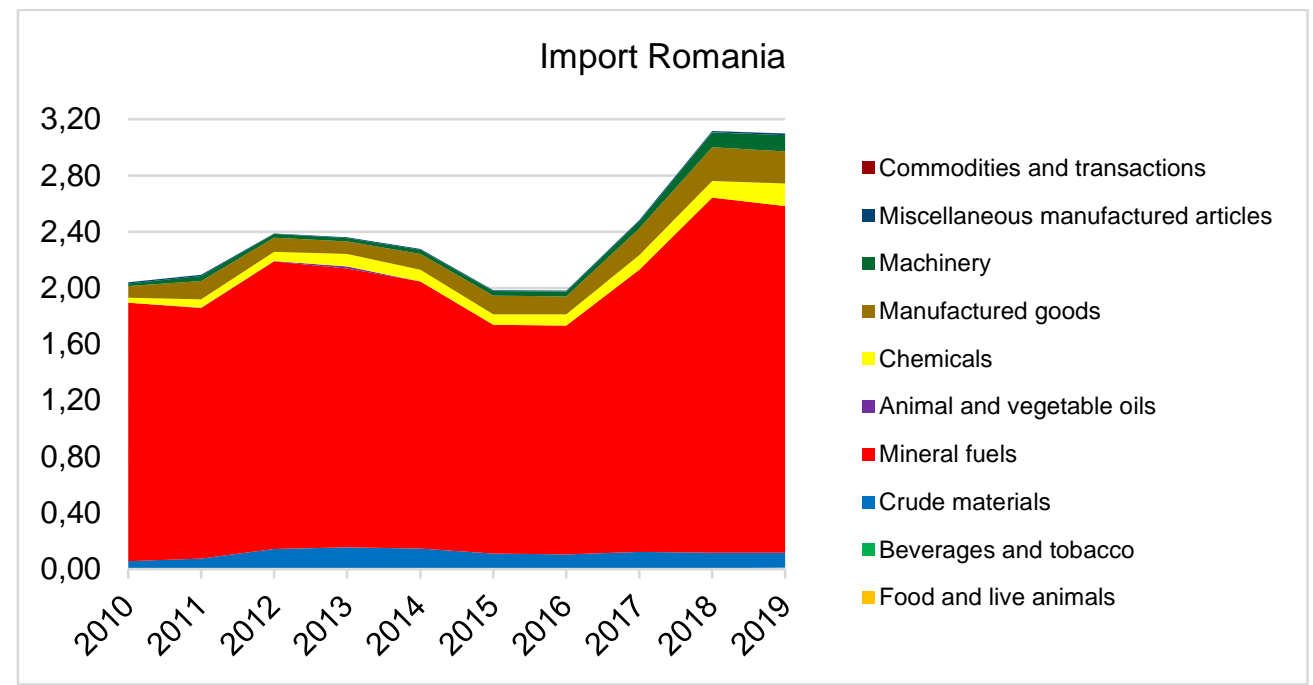

Figure 12: Romania's import from Russia, billion $€$ Source: Author's projection using Eurostat database (2021)

\section{Factors explaining the differences between the Central and Eastern European Countries}

The analysis of the historical data contributed to the discovery of some factors that can explain why the sanctions and counter-sanctions had a different impact on trade in goods between Central and Eastern European Countries and the Russian Federation. To begin with, some Member States have suffered more due to their geographical location. Being geographically close to the Russian Federation had led to a more intense bilateral trade. Following the sanctions, those countries incurred higher losses. Another finding of this research is related to how each country applied the restrictive measures against Russia. In addition, the categories of goods that dominate the imports and exports determine the existence of differences. The CEECs' exports to Russia are led by machinery and transport equipment, and Member States with a high share of machinery in their exports have experienced substantial losses. Countries, in the export structure of which, the products affected by sanctions and counter-sanctions, such as dual-use technology and agricultural products, had a higher share, suffered higher losses. CEECs that had a high share of food in their exports were affected significantly because of the food import ban imposed by the Russian Federation. Countries with relatively high levels of chemicals, raw materials and beverages in their exports suffered lower losses since these types of products were not directly affected by either the EU's economic sanctions or Russia's embargo on food products imported from European Union countries. 


\section{Conclusions}

TOM XXX, $2^{\text {nd }}$ Issue, December 2021

The research finds that in the years following the adoption of the restrictive measures, all eleven Central and Eastern European Countries saw a decline in their exports to the Russian Federation, but some states were more affected than others. CEECs' total imports from Russia also declined. Although bilateral trade has begun to recover since 2017, exports and imports still haven't managed to reach the values recorded in 2013.

Quantitative analysis of the historical data highlighted several factors that can explain why the restrictive measures had an uneven impact on trade in goods between Russia and the Member States. The differences are determined by the geographical proximity, the structure of each country's exports and the way in which the national authorities interpreted and applied the sanctions. Another finding is that Russia's principal trading partners among Central and Eastern European Countries suffered the largest losses in nominal terms. Poland, Lithuania and the Czech Republic are the states with the highest exports to Russia, which means these countries were the most affected by the decreasing exports to the Russian Federation.

Some categories of products were more severely affected than others. Thus, the structure of exports and imports of each country played a decisive role in establishing the level of sensitivity to restrictive measures. Also, the structure of exports and imports influenced the evolution of bilateral trade in the next period and determined the ability to recover trade between Russia and each of the eleven Central and Eastern European Countries.

\section{References}

1. Bali, M. (2018). "The Impact of Economic Sanctions on Russia and its Six Greatest European Trade Partners: a Country SVAR Analysis", Finance \& Business, 14 (2), pp.45-67.

2. Bond I., Odendahl C., Rankin J. (2015) Frozen: The politics and economics of sanctions against Russia. CER, London, [Online], Available: https://www.cer.eu/publications/archive/policy-brief/2015/frozen-politics-andeconomics-sanctions-against-russia [19 October 2021].

3. DG EPPD (2017) Russia's sanctions: economic and trade effects, compliance and the way forward, Directorate General for Externa Policies Department, paper produced on request of the European Parliament's Committee on International Trade [Online], Available: http://www.europarl.europa.eu/RegData/etudes/ STUD/2017/603847/EXPO_STU(2017)603847_EN.pdf [20 September 2021].

4. Dolidze T. (2015) EU Sanctions Policy towards Russia: The SanctionerSanctionee's Game of Thrones, CEPS Working Document No. 402, Bruxelles. [Online], Available: https://www.ceps.eu/ceps-publications/eu-sanctions-policytowards-russia-sanctioner-sanctionees-game-thrones/ [19 October 2021].

5. European Council, EU restrictive measures in response to the crisis in Ukraine, [Online], Available: https://www.consilium.europa.eu/en/policies/sanctions/ ukrainecrisis/) [19 October 2021].

6. Eurostat, EU trade since 1988 by HS2,4,6 and CN8, [Online], Available: https://appsso.eurostat.ec.europa.eu/nui/show.do?dataset=DS-645593\&lang=en [29 November 2021]. 
7. Giumelli, F (2017) "The Redistributive Impact of Restrictive Measures on EU Members: Winners and Losers from Imposing Sanctions on Russia", Journal of Common Market Studies (JCMS), vol. 55 no. 5, pp. $1062-1080$.

8. Gurvich, E., Prilepskiy, I. (2015) "The impact of financial sanctions on the Russian economy ", Russian Journal of Economics, Elsevier, vol. 1(4), pp 359-385. 9. Havlik, P. (2019) EU-Russia sanctions exchange has had important economic and political consequences, [Online], Available: https://wiiw.ac.at/eu-russiasanctions-exchange-has-had-important-economic-and-political-consequences-n365.html [15 November 2021].

10. Ilina E. (2015) "Effect of Sanctions on Russian economy", The Review of Economy, the Law and Sociology, pp. 34-37.

11. Oxenstierna, S. (2015) The sanctions against Russia. Are there winners and losers around the Baltic Sea? Some recommendations for the policy-makers, BSR Policy Briefing 9/2018, Centrum Balticum Foundation [Online], Available: http://www.centrumbalticum.org/files/4090/BSR_Policy_Briefing_10_2018.pdf [19 October 2021].

12. Russell, M. (2018) Sanctions over Ukraine Impact on Russia, European Parliamentary Research Service, [Online], Available: https://www.europarl.europa.eu/RegData/etudes/BRIE/2018/614665/EPRS_BRI(20 18) 614665_EN.pdf [19 October 2021]. 